\title{
The level of independence in daily functioning of the elderly in home environments
}

\section{Poziom samodzielności osób starszych w zakresie funkcjonowania w życiu codziennym w środowisku zamieszkania}

\author{
Bożena Zboina ${ }^{1}$, Barbara Ślusarska², Renata Stępieńn ${ }^{3}$, Grzegorz Nowicki², Grażyna Wiraszka ${ }^{3}$ \\ ${ }^{1}$ Department of Faculty of Pedagogy and Health Sciences, The College of Business and Entrepreneurship, Ostrowiec Świętokrzyski, \\ Poland \\ Head of the Department: Grażyna Kałamaga PhD \\ ${ }^{2}$ Department of Faculty of Nursing and Health Sciences, Medical University of Lublin, Poland \\ Head of the Department: Prof. Irena Wrońska \\ ${ }^{3}$ Faculty of Medicine and Health Sciences, Jan Kochanowski University, Kielce, Poland \\ Head of the Faculty: Prof. Marianna Janion MD, PhD
}

Key words: EASY-Care questionnaire, home environment, elderly subjects.

Słowa kluczowe: kwestionariusz EASY-Care, środowisko domowe, osoby starsze.

\begin{abstract}
Introduction: Health problems in elderly patients, requiring special treatment and care, particularly home-based care, are an important challenge for healthcare providers today. Monitoring the functional status of elderly subjects is very important for subjects themselves as well as for the healthcare and social welfare providers.

Aim of the research: To determine the functional capacity and independence in daily functioning of elderly subjects residing in their home environments, including potential correlations of these factors with the prevalence of certain medical conditions. Material and methods: The study was conducted in a population of 401 elderly subjects residing at their home environments in the Ostrowiec Świętokrzyski district. The inclusion criteria included age of at least 65 years as well as full logical and verbal contact with the subject. Independence in daily functioning was assessed by means of the EASY-Care questionnaire (1999-2002 Polish version).

Results: The mean age of the subjects was 73.61 years. Vocational educational background was most prevalent. The highest prevalence was reported for eyesight problems (33.90\%) and hearing problems (27.12\%). The average score obtained by the elderly subjects in the EASY-Care daily functioning survey was $27.04 \pm 25.79$ points. Significantly lower levels of functional capacity were observed in subjects with cardiovascular disorders $(p<0.05)$ and respiratory disorders $(p<0.05)$ as compared to subjects not diagnosed with these disorders.

Conclusions: The level of independence of the elderly subjects was found to be moderate. Disorders most detrimental to the daily functioning of the elderly are those related to the respiratory and cardiovascular systems.
\end{abstract}

\section{Streszczenie}

Wprowadzenie: Problemy zdrowotne osób starszych związane z leczeniem i pielęgnowaniem, szczególnie w środowisku ich miejsca zamieszkania, stanowią bardzo aktualne wyzwanie. Monitorowanie stanu funkcjonalnego osób starszych jest niezmiernie ważne zarówno dla nich samych, jak i z punktu widzenia polityki zdrowotnej oraz społecznej.

Cel pracy: Określenie poziomu sprawności funkcjonalnej oraz samodzielności w zakresie funkcjonowania w życiu codziennym osób starszych zamieszkałych w środowiskach domowych oraz ich związku z występowaniem uwarunkowań chorobowych wśród badanych.

Materiał i metody: Badaniem objęto 401 osób starszych w środowisku ich zamieszkania w powiecie ostrowieckim. Kryterium doboru grupy stanowiły: ukończony 65. rok życia i pełny logiczny kontakt słowny. Do oceny samodzielności w zakresie funkcjonowania w życiu codziennym zastosowano kwestionariusz EASY-Care (wersja polska 1999-2002).

Wyniki: Średnia wieku badanych wynosiła 73,61 roku, przeważało wykształcenie zawodowe. W największym odsetku u osób starszych występowały problemy ze wzrokiem $(33,90 \%)$ i słuchem $(27,12 \%)$. W ocenie skali funkcjonalnej czynności życia codziennego wg EASY-Care seniorzy uzyskali w grupie średni wynik $27,04 \pm 25,79$ pkt. Stwierdzono istotnie niższy poziom funkcjonowania w życiu codziennym osób starszych z chorobami układu krążenia $(p<0,05)$ oraz układu oddechowego $(p<0,05)$ w porównaniu z seniorami bez takich rozpoznań.

Wnioski: Samodzielność osób starszych jest na średnim poziomie. Schorzeniami, które najbardziej zaburzają funkcjonowanie osób starszych, są choroby układu krążenia i układu oddechowego. 


\section{Introduction}

In the process of aging, numerous degenerative processes occur in nearly all organs and systems which markedly reduce the functional capacity of subjects. In addition, chronic diseases, frequently associated with numerous complaints and inabilities, become more prevalent in elderly subjects [1].

Health problems in elderly patients, requiring special treatment and care, particularly home-based care, are an important challenge for healthcare providers today. Monitoring the functional status of elderly subjects is very important for subjects themselves as well as for their healthcare and social welfare providers. For appropriate assistance to be provided to the elderly, care systems should be developed including precise identification of the roles and responsibilities of physicians, nurses, psychologists, occupational therapy providers, physiotherapists, social workers, and volunteers, as well as the role of local governments in the activation of elderly residents [2]. In developed countries, numerous organisational forms of support for the elderly are available. An important role in such a system is played by professionally trained nurses who provide home-based care and support. Due to the increasing geriatric population in Poland, there is a need for properly-targeted healthcare and social welfare policies implemented so as to provide for the needs and problems of individuals in this age group [3]. According to the demographic forecast of Statistics Poland, in 2035 the subpopulation of individuals aged 65 years or more will have increased by $62 \%$ as compared to 2010, while the subpopulation of individuals aged 80 years or more will have increased by as much as $96 \%$. The percentage of the elderly within the general population will differ by region [4]. Aging populations are one of the main causes of increased demand for medications and home-based care provided by nurses and informal caretakers [5]. Elderly individuals spend $70-80 \%$ of the time at home. Due to multimorbidity rates that increase with age, a significant number of elderly subjects are in need of medical care. According to estimates, multimorbidity may affect more than $80 \%$ of subjects above the age of 84 years [6]. Multiple chronic comorbidities reduce the functional capacity and the quality of life, and increase social isolation, poor prognosis, and mortality rates [7]. Therefore, comprehensive clinical approach and early detection of comorbidities are required along with systematic evaluation of subjects' functional capacity and provision of appropriate support.

\section{Aim of the research}

The objective of the study was to determine the functional capacity and independence in daily functioning of elderly subjects residing at their home environments, including potential correlation of these factors with the prevalence of certain medical conditions.

\section{Material and methods}

The study was conducted in a population of 401 elderly subjects residing in their home environment, who received medical services from primary healthcare providers in the town of Ostrowiec Swiętokrzyski. The inclusion criteria included age of at least 65 years, health condition permitting the completion of the questionnaire, and full logical and verbal contact with the subject.

The study was carried out by means of a diagnostic survey. A validated Polish version of the international EASY-Care questionnaire (1999-2002 Polish version) was used in the survey [8]. EASY-Care is a tool for comprehensive assessment of the functional capacity and sociomedical needs of elderly subjects in their home environment. It consists of several modules including questions that assess the subject's eyesight, hearing, communication, ability to chew, emotional status, activities of daily living and instrumental activities of daily living (ADL, IADL), and identification of individuals providing help with individual activities. With regard to the ADL and IADL-related functioning, subjects can score a maximum of 100 points, with scores of $0-20$ points corresponding to the mildest incapacity (mild patient condition), scores of 21-85 points corresponding to moderate patient condition, and scores of $86-100$ points corresponding to severe patient condition [8].

When responding to each question, subjects were asked to indicate whether they were capable of performing a particular task independently or whether they required help from other individuals. The following scoring thresholds were used: 1 point - no need for support, full independence; 2 points - occasional need for help from others, partial dependence; and 3 points - need for help from others. Based on the EASY-Care survey results, the need for support in five areas, including eyesight, hearing, and communication (questions 11, 12, 14, 21), housing conditions (question 16), health and well-being (question 15), sense of loneliness and self-care (questions 17, 18, 28), and walking outside (questions 19, 20, 22, 23), was assessed.

The research was carried out in accordance with the guidelines of the Helsinki Declaration of 2013.

\section{Statistical analysis}

The study assessed quantitative as well as qualitative variables. Statistical analyses were carried out using the PQStat statistical software package version 1.6.4.110. The distribution of responses to the questions of the EASY-Care questionnaire and the overall activities of daily living (ADL) score obtained depend- 
ing on the comorbidities in medical history were analysed using Mann-Whitney's U-test. Test probability of $p<0.05$ was defined as significant, while the test probability of $p<0.01$ was defined as highly significant. Basic statistical measures, such as arithmetic mean (M), standard deviation (SD), and median (Me), were determined as means for the analysis of tested variables.

\section{Results}

\section{Study group characteristics}

Overall, the study group consisted of 401 subjects, including 237 (58.23\%) females and 169 (41.77\%) males. The mean age of the subjects was $73.61 \pm 9.68$. The highest percentage of subjects had vocational educational background $(43.86 \%$ of males and $30.65 \%$ of females) followed by subjects with secondary school background (28\% of males and $32.26 \%$ of females). The most common disorders diagnosed in patients within the study group included cardiovascular disorders $(M=26.84)$, respiratory disorders $(M=28.25)$, skeletal and articular disorders $(\mathrm{M}=23.77)$, and diabetes $(\mathrm{M}=20.17)$.

\section{Sensory capability and overall health in the study group as assessed using the EASY-Care questionnaire}

The first eight items of the EASY-Care scale are used to assess subjects' capabilities as regards their eyesight, hearing, communication, ability to chew, and speak, while also facilitating determination of their overall health, loneliness, and housing conditions.

As demonstrated by our study, the mean sensory capability as assessed using the scale of 4 to 12 (where 4 was the best sensory capability and 12 was no sensory capability) in the study group amounted to 5.14 \pm 1.94 . The highest percentages of subjects reported eyesight problems $(33.90 \%)$ and hearing problems $(27.12 \%)$

The mean assessment of health as assessed using a scale of 1 to 5 ( 1 being the best score and 5 being the worst score) amounted to $3.77 \pm 0.72$. The elderly patients evaluated their health to be average (53.39\%), very good $(3.39 \%)$, good $(29.66 \%)$, or poor $(13.56 \%)$.

The mean score in the category of loneliness as assessed on a 0 to 3 scale ( 0 being the best score and 3 being the worst score) amounted to $1.33 \pm 0.65$. Scores obtained for this item ranked the lowest among all analysed items. Loneliness was perceived frequently by $43 \%$ and occasionally by $47 \%$ of responders. The mean score in terms of housing conditions as assessed on a 1 to 5 scale ( 1 being the best score and 5 being the worst score) amounted to $3.34 \pm 0.79$. Nearly half of the responders assessed their housing conditions to be good (48.33\%), while one third of the population considered their housing conditions to be average (31.67\%). Details are presented in Table 1.

\section{EASY-Care functional capacity scores} and range of help required in daily problems

The mean activities of daily living (ADL, IADL) scores in the group amounted to $27.04 \pm 25.79$, with the median of 19.5 points (minimum of 0 , maximum of 100 points). Details are presented in Table 2.

As shown by the results, a large majority of elderly subjects retains their functional capacity as assessed by the EASY-Care tool (59.46\%). Moderate functional capacity deficits were observed in $37.59 \%$ of subjects while the most severe incapacity was observed in $2.95 \%$ of the study population. Details are presented in Table 3.

With regard to the instrumental activities of daily living (IADL), the highest incapacity score was obtained for walking outside $(M=2.43)$. The lowest scores were obtained for home maintenance $(M=0.97)$ and using telephone $(M=0.87)$. With regard to the basic activities of daily living (ADL), the highest incapacity score was obtained for using bath/shower $(M=3.15)$, while the lowest score was obtained for having meals $(\mathrm{M}=0.38)$.

Only 119 out of the 401 (29.67\%) subjects, including 57 (14.21\%) males and 62 (15.46\%) females, provided answers to questions regarding their need for supportive care. The mean functional capacity score for this subgroup was $23.35 \pm 5.25$. Most help was required by the elderly with regard to walking outside, home maintenance, shopping, walking up and down stairs, managing finances, using the phone, and walking around the house. The largest group of care providers consisted of friends, neighbours, and family members. The need for public and paid help was reported less frequently. In addition, the subjects reported the lack of available help with regard to the ADL and IADL tasks subject to the assessment. Such declarations were provided by subjects scoring 3.96 to 20 points. Details are presented in Table 2 .

Differences in the functional capacity and the sense of loneliness in relation to the prevalence of medical disorders in the elderly subjects

Significant differences were observed in terms of activities of daily living as well as instrumental activities of daily living among the elderly subjects depending on the prevalence of selected comorbidities. Significantly lower levels of functional capacity were observed in subjects with cardiovascular disorders $(p<0.05)$ and respiratory disorders $(p<0.05)$ as compared to subjects not diagnosed with these disorders. No significant differences were observed between the elderly subjects in terms of the prevalence of diabetes and skeletal articular system disorders. Details are presented in Table 4

In the assessment of loneliness, the mean and median scores in the group of subjects with no disorders 
Table 1 . Sensory capability and overall health in the study group

\begin{tabular}{|c|c|c|c|c|c|}
\hline Easy-Care Scale & Mean & Standard deviation & Score & Answers & Percentage \\
\hline \multirow[t]{3}{*}{ Eyesight } & \multirow[t]{3}{*}{5.14} & \multirow[t]{3}{*}{1.94} & 1 & Yes & 61.02 \\
\hline & & & 2 & With difficulty & 33.90 \\
\hline & & & 3 & Not at all & 5.08 \\
\hline \multirow[t]{3}{*}{ Hearing } & & & 1 & Yes & 67.80 \\
\hline & & & 2 & With difficulty & 27.12 \\
\hline & & & 3 & Not at all & 5.08 \\
\hline \multirow[t]{3}{*}{ Communication } & & & 1 & No difficulty & 70.83 \\
\hline & & & 2 & With difficulty & 25.00 \\
\hline & & & 3 & With significant difficulty & 4.17 \\
\hline \multirow[t]{3}{*}{ Chewing } & & & 1 & No difficulty & 61.21 \\
\hline & & & 2 & Some difficulty & 35.34 \\
\hline & & & 3 & Inability to chew & 3.45 \\
\hline \multirow[t]{5}{*}{ Overall health } & \multirow[t]{5}{*}{3.77} & \multirow[t]{5}{*}{0.72} & 1 & Excellent & 0.00 \\
\hline & & & 2 & Very good & 3.39 \\
\hline & & & 3 & Good & 29.66 \\
\hline & & & 4 & Moderate & 53.39 \\
\hline & & & 5 & Poor & 13.56 \\
\hline \multirow[t]{3}{*}{ Loneliness } & \multirow[t]{3}{*}{1.33} & \multirow[t]{3}{*}{0.65} & 0 & Never & 10 \\
\hline & & & 1 & Sometimes & 47 \\
\hline & & & 2 & Frequently & 43 \\
\hline \multirow{5}{*}{$\begin{array}{l}\text { Overall housing } \\
\text { conditions }\end{array}$} & \multirow[t]{5}{*}{3.34} & \multirow[t]{5}{*}{0.79} & 0 & Excellent & 0.00 \\
\hline & & & 2 & Very good & 12.5 \\
\hline & & & 3 & Good & 48.33 \\
\hline & & & 4 & Moderate & 31.67 \\
\hline & & & 5 & Poor & 7.5 \\
\hline
\end{tabular}

in medical history amounted to $\mathrm{M}=1.5$ and $\mathrm{Me}=2$, respectively. In the group of patients with comorbidities, the respective values were $\mathrm{M}=1.23$ and $\mathrm{Me}=1$. The results obtained in the group were significantly different $(Z=1.9758, p<0.05)$. Subjects with comorbidities reported a significantly higher sense of loneliness (Table 5).

\section{Discussion}

The monitoring of the functional capability of elderly subjects in home environments is a very important element of community support for the geriatric population. Quintennial assessments using appropriate scales should become common practice in primary health care provided to individuals above the age of 60 years. This would allow for detection of numerous disorders, evaluation of a subject's capacity and ability to independently function in home environment, as well as identification of subjects requiring compre- hensive geriatric care provided by specialist teams [5]. In the Polish and foreign literature, the EASY-Care questionnaire is mentioned as a useful tool in nursing care for elderly patients $[8,9]$.

As shown in the study, elderly subjects who reside at home differ in their needs for additional support. More than $50 \%$ of subjects reported mild difficulties in daily functioning. As demonstrated by Schlegel-Zawadzka et al. [10], a significant number, i.e. $64.9 \%$, of elderly subjects remained independent with respect to the activities of daily living at home, while only $26.3 \%$ of patients required moderate help from others. These results are similar to those obtained in this study. As shown by Dziechciaż et al. [11] in a group of 102 elderly residents of rural areas (aged 60-86 years), $90.2 \%$ of subjects in the study group were characterised by mild loss of self-care capacity as assessed by the ADL scale. However, a large majority of subjects $(66.7 \%)$ presented with moderate-level deficits with regard to the instrumental activities of daily life 
Table 2. EASY-Care functional capacity scores in subjects reporting help being obtained from a care provider

\begin{tabular}{|c|c|c|c|c|c|c|c|c|c|}
\hline \multirow[t]{2}{*}{$\begin{array}{l}\text { Functions: } \\
\text { IADL; ADL }\end{array}$} & \multirow{2}{*}{$\begin{array}{c}\text { Mean } \\
\text { (standard } \\
\text { deviation) }\end{array}$} & \multirow[t]{2}{*}{$\begin{array}{l}\text { Min.- } \\
\max .\end{array}$} & \multicolumn{7}{|c|}{$\begin{array}{l}\text { Who is providing help? } \\
\text { (\% of subjects dependent in the performance of ADL and IADL) }\end{array}$} \\
\hline & & & Spouse & $\begin{array}{l}\text { Family } \\
\text { member }\end{array}$ & $\begin{array}{l}\text { Friend, } \\
\text { neighbour }\end{array}$ & $\begin{array}{l}\text { Paid } \\
\text { help }\end{array}$ & $\begin{array}{l}\text { Public } \\
\text { help }\end{array}$ & $\begin{array}{l}\text { Other } \\
\text { person }\end{array}$ & $\begin{array}{l}\text { No help } \\
\text { available }\end{array}$ \\
\hline \multicolumn{10}{|c|}{ Instrumental activities of daily living (IADL): } \\
\hline $\begin{array}{l}\text { Home } \\
\text { maintenance }\end{array}$ & $0.97(0.89)$ & $0-3$ & 3.96 & 25.74 & 31.68 & 5.94 & 11.88 & 15.84 & 3.96 \\
\hline Walking outside & $2.43(2.38)$ & $0-6$ & 1.37 & 24.66 & 36.99 & 8.22 & 6.85 & 12.33 & 9.59 \\
\hline Shopping & $1.76(1.38)$ & $0-4$ & 1.07 & 27.96 & 30.11 & 9.68 & 9.68 & 16.13 & 5.38 \\
\hline Preparing meals & $1.57(1.73)$ & $0-5$ & 4.76 & 22.62 & 20.00 & 14.29 & 9.52 & 16.67 & 5.95 \\
\hline $\begin{array}{l}\text { Walking up } \\
\text { and down stairs }\end{array}$ & $1.65(1.77)$ & $0-5$ & 2.50 & 26.25 & 35.00 & 11.25 & 7.50 & 8.75 & 8.75 \\
\hline Managing finances & $1.1(1.34)$ & $0-4$ & 1.41 & 29.58 & 36.62 & 4.22 & 8.45 & 14.08 & 5.63 \\
\hline Taking medications & $1.12(1.34)$ & $0-4$ & 0.00 & 19.12 & 26.47 & 13.23 & 20.59 & 11.76 & 8.82 \\
\hline Using phone & $0.87(0.65)$ & $0-3$ & 0.00 & 24.72 & 41.57 & 2.25 & 4.49 & 16.85 & 10.11 \\
\hline \multicolumn{10}{|c|}{ Self-care activities (activities of daily living - ADL): } \\
\hline $\begin{array}{l}\text { Walking around } \\
\text { the house }\end{array}$ & $1.76(2.74)$ & $0-9$ & 5.88 & 17.65 & 33.33 & 5.88 & 9.80 & 11.76 & 13.72 \\
\hline Using bath/shower & $3.15(3.01)$ & $0-6$ & 1.39 & 25.00 & 15.28 & 22.22 & 15.28 & 15.28 & 5.56 \\
\hline $\begin{array}{l}\text { Urinary } \\
\text { incontinence }\end{array}$ & $0.54(0.49)$ & $0-8$ & 3.12 & 23.44 & 12.50 & 12.50 & 12.5 & 23.44 & 12.50 \\
\hline Dressing oneself & $1.21(1.8)$ & $0-6$ & 3.70 & 35.18 & 14.81 & 9.26 & 9.26 & 14.81 & 12.96 \\
\hline Transferring & $0.65(0.56)$ & $0-7$ & 5.77 & 17.31 & 28.85 & 11.54 & 5.77 & 15.38 & 15.38 \\
\hline $\begin{array}{l}\text { Personal } \\
\text { appearance care }\end{array}$ & $1.17(2.12)$ & $0-5$ & 0.00 & 22.22 & 22.22 & 11.11 & 8.89 & 15.56 & 20.0 \\
\hline Using restroom & $1.48(2.54)$ & $0-8$ & 2.08 & 27.08 & 20.83 & 16.67 & 8.33 & 10.42 & 14.58 \\
\hline $\begin{array}{l}\text { Faecal } \\
\text { incontinence }\end{array}$ & $0.47(0.38)$ & $0-9$ & 0.00 & 26.09 & 10.87 & 17.39 & 13.04 & 17.39 & 15.22 \\
\hline Eating meals & $0.38(0.24)$ & $0-5$ & 2.50 & 25.00 & 20.00 & 17.50 & 7.50 & 12.50 & 12.50 \\
\hline $\begin{array}{l}\text { Overall } \\
\text { ADL and IADL }\end{array}$ & $\begin{aligned} M & =27.04 \\
(S D & =25.79)\end{aligned}$ & $0-100$ & & & & & & & \\
\hline
\end{tabular}

(IADL). As shown by Bogusz et al. [12] in a group of 100 subjects above the age of 70 years, subjects with high functional capacity were predominant among rural residents. However, self-care independence of subjects was reduced with age with a simultaneous increase being observed with regard to the need for help, care, and financial support.

Studies by Doroszkiewicz et al. [13] and by Bujnowska-Fedak et al. [14] confirmed that the management of finances, shopping, walking outside, as well as heavier home maintenance tasks and bathing were among the activities for which the signs of deterioration were observed earliest, and which significantly reduced the independence of subjects in their environments. Such a range of independence deficits was also compared in this study.

The aging process naturally contributes to the reduced capacities of individuals, and advanced age is one of the most constant factors responsible for the differences between fully capable individuals and those with physical and intellectual deficits. According to Statistic Poland's 2016 report on the health of Polish residents, problems with independent walking up and down stairs (one story, without any help) were reported by $30 \%$ of individuals aged $60-69$ years, more than half of individuals aged 70-79 years, and nearly $80 \%$ of individuals aged 80 years or more. In addition, as shown by the general information obtained in this study, one in three individuals aged 65 years or more experiences problems with daily self-care activities such as taking a bath or a shower, lying down and getting out of bed, sitting down and standing up from a chair, dressing and undressing, using the toilet, and having meals [15].

The degree of capability in elderly subjects depends on the process of aging as well as on the comor- 
Table 3. Patient status as assessed using the EASY-Care tool

\begin{tabular}{|lcc|}
\hline Patient status & $\boldsymbol{N}$ & Percentage \\
Mild & 242 & 59.46 \\
Moderate & 153 & 37.59 \\
Severe & 12 & 2.95 \\
\hline
\end{tabular}

bidities, lifestyle, and socio-environmental as well as emotional factors at work throughout the individual's life. In the study conducted by Wysokiński et al. [16] in a group of 150 subjects above the age of 65 years, no statistically significant differences were observed between the disability level (ADL, IADL) and the number of comorbidities. However, the results of our studies suggest that cardiovascular and respiratory disorders prevalent among the elderly subjects reduce their functional capability (as assessed by ADL and IADL). In such situations, support from close ones as well as professional care providers is required; in many cases, this results in the subject becoming dependent on others or requiring support from a longterm care institution [1, 17-21].

In a paper by Talarska et al. it was shown that in the EASY-Care assessment, study participants required partial support in the following areas: mental health and well-being (59\%), maintaining health (29\%), mov- ing (22\%), and seeing, hearing, and communication (22\%). It was also found that the need for 24-hour care was significantly influenced by the following factors: urinary incontinence, difficulties in undertaking physical activity outside the home, depression, and oblivion [22]. Studies by Głowacka et al. [23] indicate the conditioning of functional capacity of seniors at home by many factors, such as age, sex, education, place of residence, self-assessment of their own health, and housing with another family member. The authors emphasise that these factors overlap most often creating a certain individual layout. In our own studies, the functional possibilities of the patients under study significantly worsened the chronic diseases of the cardiovascular and respiratory systems.

However, the authors hope that the obtained results may be used as a basis for further research aimed at identification of the specific requirements for the home-based support of elderly subjects, with consideration being paid to their needs and problems related to detrimental effects of geriatric age.

\section{Conclusions}

Functional independence of elderly subjects in the study group as assessed using the EASY-Care questionnaire corresponded to moderate loss in complex daily life activities and self-care ability. Neighbours

Table 4. Functional capacity as assessed by EASY-care questionnaire in groups of elderly subjects with comorbidities as compared to elderly subjects with no medical history

\begin{tabular}{|lccccc|}
\hline Disorders & \multicolumn{2}{c}{ Absent } & \multicolumn{2}{c}{ Present } & $\begin{array}{c}\text { Mann-Whitney } \\
\text { U-test }\end{array}$ \\
\cline { 2 - 5 } & $\begin{array}{c}\text { Mean } \\
\text { (standard } \\
\text { deviation) }\end{array}$ & $\begin{array}{c}\text { Median } \\
\text { (interquartile } \\
\text { range) }\end{array}$ & $\begin{array}{c}\text { Mean } \\
\text { (standard } \\
\text { deviation) }\end{array}$ & $\begin{array}{c}\text { Median } \\
\text { (interquartile } \\
\text { range) }\end{array}$ & \\
$\begin{array}{l}\text { Cardiovascular } \\
\text { system }\end{array}$ & $20.68(23.48)$ & $12.00(26.00)$ & $26.84(27.00)$ & $17.0(934.00)$ & $\begin{array}{c}Z=2.490 \\
p=0.0125^{*}\end{array}$ \\
Respiratory system & $22.24(24.94)$ & $13.00(30.50)$ & $28.25(26.00)$ & $21.00(33.00)$ & $\begin{array}{c}Z=2.449 \\
p=0.0143^{*}\end{array}$ \\
$\begin{array}{l}\text { Skeletal articular } \\
\text { system }\end{array}$ & $23.16(25.41)$ & $14.00(32.00)$ & $23.77(24.88)$ & $15.00(31.00)$ & $\begin{array}{c}Z=0.479 \\
p=0.6316\end{array}$ \\
Diabetes & $23.68(25.66)$ & $14.00(32.00)$ & $20.17(20.50)$ & $14.00(21.00)$ & $\begin{array}{c}Z=0.3371 \\
p=0.7360\end{array}$ \\
\hline
\end{tabular}

$Z$ - the value of the Mann-Whitney U-test statistic, $p$ - the significance level, ${ }^{*} p<0.05$.

Table 5. Sense of loneliness depending on the prevalence of comorbidities within the study group

\begin{tabular}{|c|c|c|c|c|c|c|c|c|c|}
\hline Variable & $\begin{array}{c}\text { Disorders } \\
\text { in medical } \\
\text { history }\end{array}$ & Mean & $\begin{array}{l}\text { Standard } \\
\text { deviation }\end{array}$ & $\begin{array}{l}\text { Mini- } \\
\text { mum }\end{array}$ & $\begin{array}{l}\text { Lower } \\
\text { quartile }\end{array}$ & Median & $\begin{array}{l}\text { Upper } \\
\text { quartile }\end{array}$ & $\begin{array}{l}\text { Maxi- } \\
\text { mum }\end{array}$ & $\begin{array}{c}\text { Mann- } \\
\text { Whitney } \\
U \text {-test }\end{array}$ \\
\hline \multirow[t]{3}{*}{ Loneliness } & No & 1.5 & 0.61 & 0 & 1 & 2 & 2 & 2 & \multirow{2}{*}{$\begin{array}{c}Z=1.9758 \\
p=0.0482^{*}\end{array}$} \\
\hline & Yes & 1.23 & 0.66 & 0 & 1 & 1 & 2 & 2 & \\
\hline & Overall & 1.33 & 0.65 & 0 & 1 & 1 & 2 & 2 & \\
\hline
\end{tabular}

$Z$ - the value of the Mann-Whitney U-test statistic; $p$ - the significance level, ${ }^{*} p<0.05$. 
and friends, as well as family members, constitute the group supporting elderly subjects in their daily functioning. Disorders most detrimental to the daily functioning of the elderly are those related to the respiratory and cardiovascular systems, and diabetes. Elderly subjects burdened with respiratory or cardiovascular diseases are characterised by significantly lower functional capability compared to subjects with no diseases of these systems in their medical history.

\section{Conflict of interest}

The authors declare no conflict of interest.

\section{References}

1. Wieczorowska-Tobis K. Zmiany narzadowe $\mathrm{w}$ procesie starzenia. Pol Arch Med Wewn 2008; 118 (Suppl): 63-9.

2. Bień B, Błędowski P, Broczek K, Derejczyk J, Grodzicki T, Kędziora-Kornatowska K, Kokoszka-Paszkot J, Przygucka-Gawlik M, Klich-Raczka A, Kostka T, Machaj Z, Szczerbińska K, Wieczorowska-Tobis K, Żak M. Standardy postępowania $\mathrm{w}$ opiece geriatrycznej. Stanowisko Polskiego Towarzystwa Gerontologicznego opracowane przez ekspertów Zespołu ds. Gerontologii przy Ministrze Zdrowia. Gerontol Pol 2013; 21: 33-47.

3. Muszalik M, Biercewicz M. Problemy opiekuńcze u osób w starszym wieku. In: Pielęgniarstwo w Opiece Długoterminowej: Podręcznik dla Studiów Medycznych. Kędziora-Kornatowska K, Muszalik M, Skolmowska E (eds.). Wydaw. Lek. PZWL, Warsaw 2010; 131-9.

4. Sytuacja demograficzna osób starszych i konsekwencje starzenia się ludności Polski w świetle prognozy na lata 2014-2050. Główny Urząd Statystyczny, Warsaw 2014. www.http://stat.gov.pl./ Access 18/12/2017

5. Fal MA (ed). Rekomendacje zmian systemowych w opiece nad osobami starszymi w Polsce. Narodowy Instytut Geriatrii, Reumatologii i Rehabilitacji, Warsaw 2016.

6. Salve ME. Multimorbidity in older adults. Epidemiol Rev 2013; 35: 75-83.

7. Vogeli C, Shields AE, Lee TA, Gibson TB, Marder WD, Weiss $\mathrm{KB}$, Blumenthal D. Multiple chronic conditions: prevalence, health consequences and implications for quality, care management and costs. J Gen Intern Med 2007; 22 Suppl. 3: 391-5.

8. Bień B. Projekt grupowy SCOPE: System oceny ludzi starych: EASY-Care - polska adaptacja 1999-2002. Klinika i Oddział Geriatrii Akademia Medyczna w Białymstoku Szpital MSWiA w Białymstoku; Białystok 2008.

9. Craig C, Chadborn N, Sands G, Tuomainen H, Gladman J. Systematic review of EASY-Care needs assessment for community-dwelling older people. Age Ageing 2015; 44: 559-65.

10. Schlegel-Zawadzka M, Klich A, Kubik B, Kołpa M. Ocena zdolności ludzi starszych do samoobsługi i samoopieki z uwzględnieniem zachowań żywieniowych. Pielęg XXI w 2011; 2: 5-9.

11. Dziechciaż M, Płaszewska-Żywko L, Guty E. Independence of elderly persons living in the rural areas in performing basic and complex everyday activities. Zdr Publ 2010; 120: 346-50.

12. Bogusz R, Charzyńska-Gula M, Szkuat M, Kocka K, Szadowska-Szlachetka Z. Sprawność funkcjonalna osób po- wyżej 70. roku życia na wsi a zapotrzebowanie na opiekę. Med Og Nauk Zdr 2013; 19: 517-22.

13. Doroszkiewicz H, Sierakowska M, Lewko J, Ostrowska A. Ocena stanu funkcjonalnego pacjentów geriatrycznych wyznacznikiem zakresu opieki pielęgniarskiej. Probl Piel 2014; 22: 258-64.

14. Bujnowska-Fedak MM, Kumiegga P, Sapilak BJ. Assessment of functional capacity of elderly persons in family practice based on selected scale tests. Fam Med Primary Care Rev 2013; 15: 76-9.

15. Zdrowie osób starszych w świetle badań statystyki publicznej. Notatka Informacyjna Sejmowej Komisji Polityki Senioralnej. Główny Urząd Statystyczny, Warszawa 2016. https://stat.gov.pl/files/gfx/portalinformacyiny/pl/defaultaktualnosci/5468/24/1/1/ludnosc_w_wieku_60._struktura_demograficzna_i_zdrowie.pdf Access 14/12/2017.

16. Wysokiński M, Fidecki W, Gębala S. Evaluation of independence in elderly people hospitalised in internal medicine units). Gerontol Pol 2013; 21: 89-97.

17. Wizner B, Skalska A, Klich-Rączka A, Piotrowicz K, Grodzicki P. Ocena stanu funkcjonalnego u osób w starszym wieku. In: Aspekty Medyczne, Psychologiczne, Socjologiczne i Ekonomiczne Starzenia się Ludzi w Polsce. Mossakowska M, Więcek A, Błędowski P (eds). Termedia, Poznań 2012; 81-94.

18. Wieczorkowska-Tobis K, Talarska D. Geriatria i Pielegniarstwo Geriatryczne. Wydawnictwo Lekarskie PZWL, Warsaw 2017.

19. Fuhrmann AC, Becker Kottwitz Bierhals CC, dos Santos NO, Paskulin LM. Association between the functional capacity of dependent elderly people and the burden of family caregivers. Rev Gaucha Enferm 2015; 36: 14-20.

20. Dziechciaż M, Wróblewska IM, Chmielewski J, Guty E, Balicka-Adamik L, Filip R, Szpringer M. Determinanty długoterminowej domowej opieki pielęgniarskiej wśród osób po 65. roku życia zamieszkałych w środowisku wiejskim. Stud Med 2018; 34: 141-6.

21. Dziechciaż M, Wróblewska IM, Talarska D, Chmielewski J, Filip R, Szpringer M. Potrzeba domowej opieki geriatrycznej a funkcjonowanie fizyczne, psychiczne i społeczne osób po 65. roku życia. Stud Med 2017; 33: 81-7.

22. Talarska D, Tobis S, Kotkowiak M, Strugała M, Stanisławska J, Wieczorowska-Tobis K. Determinants of quality of life and the need for support for the elderly with good physical and mental functioning. Med Sci Monit 2018; 24: 1604-13.

23. Głowacka M, Brudzińska I, Kornatowski T, Zabielska P, Haor Jurczak A, Karakiewicz B. Functional ability of elderly people living in their home environment according to the NOSGER. Gerontol Pol 2017; 25: 242-7.

\section{Address for correspondence:}

\section{Renata Stępień MD}

Department of Faculty of Medicine

and Health Sciences

Jan Kochanowski University

al. IX Wieków Kielc 19, 25-805 Kielce, Poland

Phone: +48 501208834

E-mail: renata.stepien@ujk.edu.pl 